\title{
ASPECTS OF COMORBIDITY SOMATOFORM DISORDERS AND ADDICTIVE BEHAVIOR IN ADOLESCENCE
}

\author{
Chernyshov O. V., Zak M. Yu.
}

\section{INTRODUCTION}

Nowadays one of the most common types of mental disorders is somatoform disorders. Most of them are represented by somatoform dysfunction syndrome: first of all, functional disorders of the cardiovascular system and gastrointestinal tract, as well as pain. Somatoform Dysfunction Syndrome - is frequent mental pathology in adolescence in somatic practice. Therefore, early diagnosis and effective treatment of somatoform dysfunction syndrome in adolescence - is the most important task of modern psychiatry, as the complexity of their differential diagnosis and therapy is connected with the fact that a significant pathogenetic role in the development of psychopathology is played by psychological mechanisms and social factors ${ }^{1}$.

Clinical pathogenetic basis of somatoform dysfunction syndrome is dysregulations ofsuprasegmental vegetative structures, developing as a systemic reaction of higher nervous and mental activity on acute or chronic emotional stress. So somatoform dysfunction syndrome manifests as vegetative disorders, various emotional and cognitive and behavioral disorders, in which intrapersonal psychological conflict is not expressed by psychopathological symptoms, but by somatic equivalents - somatoform neurotic complex of symptoms ${ }^{2}$.

Somatoform dysfunction syndrome in the pathogenic sense is a systemic response of the higher nervous and mental activity to acute or chronic emotional stress. Dysfunction, which develops as a result of autonomic dysregulation of suprasegmental structures, manifests itself mainly as actual vegetative and emotional-cognitive disorders and behavioral disorders, especially in adolescence ${ }^{3}$. Somatoform

\footnotetext{
${ }^{1}$ Smulevich A.B. Psychosomatic disorders. Manual of Psychiatry (Eds. Tiganova A.S.). Moscow : Medicine, 2000. P. 466-490.

${ }^{2}$ Oleh V. Chernyshov, MaksimY. Zak, Nataliia N. ShawlisSvetlanaV. Zhuk,. Pain As Leading Syndrome Of The Somatoform Disorders At The Pediatricks WiadomościLekarskie. 2020. № 73(6). P. 1114-1118 DOI: 10.36740/WLek202006106.

${ }^{3}$ Timerbulatov I.F., V.L. Yoldashev Neurotic disorders in children and adolescents: the mechanisms of formation in the context of the impact of factors microsocial. Review of Psychiatry and Medical Psychology them. Spondylitis. 2008. № 2. P. 28-33.
} 
dysfunction syndrome in adolescents manifests itself as physical weakness, fatigue, headache, dizziness, sleep disorders, hyperhidrosis, tremor, false angina, a sense of suffocation or "lump" in the throat, algies different localization, muscle stiffness, and dysuric dyspeptic disorders, anxiety, depressed mood, prolonged unexplained aggressiveness and protest behavior. Chronic pain - is a state that accompanies almost all the variants of somatoform dysfunction syndrome in adolescents. The most common symptoms of chronic pain syndrome manifest themselves in adolescents cephalalgies or abdominalgies syndrome (Abdominalgies). Somatoform dysfunction syndrome, as a variant of somatoform disorders is a state, in pathogenesis of which there is a significant psychopathological component: when intrapersonal psychological conflict is not expressed in behavioral disorders or other psychopathological symptoms, but is manifested as somatic equivalents and quickly transforms into somatic diseases. Psycho-social nature - is the basis of this cluster of psychopathological disorders, when somatic symptoms become the main manifestation of the emotional and interpersonal problems in adolescents. Psychological qualities and characteristics of individual, that contribute to the formation of somatoform dysfunction syndrome in adolescence, are: psychophysical infantilism, destructive parenting styles, alexithymia ${ }^{4}$. Due to the entire complexity of the pathogenesis, somatoform dysfunction syndrome is often the basis for the development of comorbid mental and behavioral pathology 5 .

\section{The purpose and materials of the study}

To study the clinical features of formation of comorbid combination of somatoform dysfunction syndrome with the manifestations of chronic pain (Cephalalgies and Abdominalgies) and different kinds of addictive behavior in adolescents, such as chemical addiction and different types of the computer addiction.

In the study, 82 teens were surveyed: 48 girls (58.5\%) and 34 boys (41.5\%) aged 16-17 years. All teenagers are students of senior high school. Reason for seeking psychiatric help was bad or not jugulated pain without verification of any serious medical condition, that can cause similar pain. Before being referred to a psychiatrist, all adolescents were thoroughly examined in somatic clinics (Mykolaiv regional children's

4 Antropov Y. F. Psychosomatic disorders in children and adolescents. Moscow, 1997. $198 \mathrm{p}$.

${ }^{5}$ Isaev D.N. Psychosomatic disorders in children. St. Petersburg : Peter, 2000. 512 p. 
hospital and Mykolaiv city children’s hospital № 2). All adolescents gave voluntary consent to a psychiatric examination. The survey was carried out on an outpatient basis, in the most destigmatized conditions. Differential diagnostic study of patients was conducted according to the diagnostic criteria for mental and behavioral disorders in the ICD-10 ${ }^{6}$, statistical data processing was carried out by methods of variation statistics using Microsoft Excel. The study complies with: Law of Ukraine "About medicines" № 123/96-BP from 04.04.96 p., article 8; requirements of the Directive 2001/20/EU The European Parliament and the Council; Conventionon the Protection of Human Rights and Dignityin the Application of Biology and Medicine Conventionon Human Rights and Biomedicine (1997 y.), Of the Law of Ukraine "About psychiatric help"; The Declaration of Helsinki: Recommendations for Doctors in Biomedical Research with Human Involvement (1964); WHO recommendations to the Ethics Committees, conducting the examination of biomedical research; requirements of Good Clinical Practice (GCP).

\section{The results of the study}

Table 1 shows the distribution of adolescents by gender, as well as, according to the identified psychopathological nosology and in accordance with the presence of the syndrome of headache or gastralgia. It was found that the most frequent in the group of teens surveyed somatoform autonomic dysfunction with cephalgic syndrome (F45.30) was observed $-23,2 \%$ of cases. In general, among the patients studied, more than half of the somatoform dysfunction syndrome was the leading clinical manifestation of a variety of somatoform disorders $(60.9 \%)$ in 29 girls $(60.4 \%)$ and 20 boys (58.8\%). Anxiety and depressive symptoms in various disorders were fixed as a whole in $32.9 \%$ of cases: in 17 girls $(35.4 \%)$ and 10 boys $(29.4 \%)$. Least likely to cause the formation of somatoform dysfunction syndrome were asthenic symptoms within the organic CNS disorders, which mainly were detected in the boys. Among both girls and boys Cephalalgies considerably prevailed in comparison with the number of cases in which abdominal pain was presented as the leading complaint. But if the number of cases of young men with Cephalalgies $17.7 \%$ is higher than the number of patients with Abdominalgies $(\mathrm{p}<0.05)$, among young women this difference was

\footnotetext{
${ }^{6}$ The classification of mental and behavioral disorders. Clinical descriptions and guidelines for the diagnosis. Kiev : Fact, 1999. 272 p.
} 
already $37.5 \%$ - almost twice as much $(\mathrm{p}<0.01)$. An important result was the evidence that in both girls and boys in identifying hypochondriacal disorder (F45.2), and chronic pain disorder (F45.4) Abdominalgies considerably prevailed against Cephalalgies $(\mathrm{p}<0.05)$.

Table 1

Distribution of adolescents according to gender, nosological entities disorders and a leading pain syndrome (Cephalalgies and Abdominalgies), absolute amount (\%)

\begin{tabular}{|c|c|c|c|c|c|}
\hline \multirow[b]{3}{*}{ Nosological forms of disorders } & \multicolumn{5}{|c|}{ Examined patients } \\
\hline & \multicolumn{2}{|c|}{ boys, $\mathbf{N}=34$} & \multicolumn{2}{|c|}{ girls, $N=48$} & \multirow[b]{2}{*}{$\begin{array}{c}\text { Total } \\
\text { in } \\
\text { groups }\end{array}$} \\
\hline & $\begin{array}{l}\text { Cepha- } \\
\text { lalgies }\end{array}$ & \begin{tabular}{|c} 
Abdo- \\
minal- \\
gies
\end{tabular} & $\begin{array}{l}\text { Cepha- } \\
\text { lalgies }\end{array}$ & $\begin{array}{c}\text { Abdo- } \\
\text { minal- } \\
\text { gies }\end{array}$ & \\
\hline $\begin{array}{l}\text { Somatoform vegetative dysfunction } \\
\text { with Cephalalgies, F45.30 }\end{array}$ & $\begin{array}{c}6^{* *} \\
(30,0)\end{array}$ & - & $\begin{array}{l}13 * * \\
(39,4)\end{array}$ & - & $\begin{array}{c}19 \\
(23,2)\end{array}$ \\
\hline Hypochondriacal disorder, F45.2 & $\begin{array}{c}1 \\
(5,0)\end{array}$ & $\begin{array}{c}3^{*} \\
(21,4) \\
\end{array}$ & $\begin{array}{c}2 \\
(6,1)\end{array}$ & $\begin{array}{c}6^{* *} \\
(40,0)\end{array}$ & $\begin{array}{c}12 \\
(14,6)\end{array}$ \\
\hline Panic disorder, F41.0 & $\begin{array}{c}3^{*} \\
(15,0)\end{array}$ & - & $\begin{array}{c}7^{*} \\
(21,2)\end{array}$ & - & $\begin{array}{c}10 \\
(12,2)\end{array}$ \\
\hline $\begin{array}{l}\text { Slight depressive episode with } \\
\text { somatic symptoms, F32.01 }\end{array}$ & $\begin{array}{c}2 \\
(10,0)\end{array}$ & $\begin{array}{c}3 \\
(21,4) \\
\end{array}$ & $\begin{array}{c}3 \\
(9,1)\end{array}$ & $\begin{array}{c}2 \\
(13,3)\end{array}$ & $\begin{array}{c}10 \\
(12,2)\end{array}$ \\
\hline Chronic pain disorder, F45.4 & $\begin{array}{c}2 \\
(10,0)\end{array}$ & $\begin{array}{c}4^{*} \\
(28,6) \\
\end{array}$ & $\begin{array}{c}1 \\
(3,0) \\
\end{array}$ & $\begin{array}{c}3^{*} \\
(20,0)\end{array}$ & $\begin{array}{c}10 \\
(12,2)\end{array}$ \\
\hline $\begin{array}{l}\text { Somatoform autonomic dysfunction } \\
\text { with Abdominalgies, F45.31 }\end{array}$ & - & $\begin{array}{c}4 * * \\
(28,6)\end{array}$ & - & $\begin{array}{c}4 * * \\
(26,7)\end{array}$ & $\begin{array}{c}8 \\
(9,8)\end{array}$ \\
\hline $\begin{array}{l}\text { Adjustment disorder: depressive } \\
\text { reaction with Cephalalgies, F43.21 }\end{array}$ & $\begin{array}{c}2 \\
(10,0)\end{array}$ & - & $\begin{array}{c}5^{*} \\
(15,2)\end{array}$ & - & $\begin{array}{c}7 \\
(8,5)\end{array}$ \\
\hline $\begin{array}{l}\text { Asthenic organic disorder of CNS } \\
\text { with Cephalalgies, F06.6 }\end{array}$ & $\begin{array}{c}4^{*} \\
(20,0)\end{array}$ & - & $\begin{array}{c}2 \\
(6,1)\end{array}$ & - & $\begin{array}{c}6 \\
(7,3)\end{array}$ \\
\hline $\begin{array}{l}\text { Total (\%of the total number } \\
\text { of patients) }\end{array}$ & $\begin{array}{c}20 \\
(24,3)\end{array}$ & $\begin{array}{c}14 \\
(17,1)\end{array}$ & $\begin{array}{c}33^{*} \\
(40,2)\end{array}$ & $\begin{array}{c}15 \\
(18,3)\end{array}$ & $\begin{array}{c}82 \\
(100)\end{array}$ \\
\hline
\end{tabular}

$* p<0,05 ; * * p<0,01$.

As is well known, and has been said above, the somatoform dysfunction syndrome is a somatoform expression of the affective reaction to suffered chronic or acute emotional stress. So somatoform dysfunction syndrome is regarded as the conversion of the unresolved intrapersonal and interpersonal conflicts ${ }^{7}$. The results of diagnostic

7 Mendelevich V.D. Soloviev S.L. Nevrozologiya and psychosomatic medicine. Moscow : MEDpress-Inform, 2002. 608 p. 
testing adolescents showed that acute or chronic stressful situations occurred in each of the surveyed patients. Data obtained during a diagnostic interview of patients are shown in Table 2.

Table 2

Distribution of adolescents according to gender, the leading pain syndrome (Cephalalgies and Abdominalgies), presence of intrapersonal and interpersonal problems, absolute amount (\%)

\begin{tabular}{|c|c|c|c|c|c|}
\hline \multirow{3}{*}{$\begin{array}{l}\text { The content of the } \\
\text { problems }\end{array}$} & \multicolumn{5}{|c|}{ examined patients } \\
\hline & \multicolumn{2}{|c|}{ boys, $N=34$} & \multicolumn{2}{|c|}{ girls, $N=48$} & \multirow[b]{2}{*}{$\begin{array}{l}\text { Total } \\
\text { in } \\
\text { groups }\end{array}$} \\
\hline & $\begin{array}{l}\text { Cepha- } \\
\text { lalgies, } \\
\mathbf{N}=\mathbf{2 0}\end{array}$ & \begin{tabular}{|l} 
Abdomi- \\
nalgies, \\
$\mathrm{N}=14$
\end{tabular} & $\begin{array}{l}\text { Cepha- } \\
\text { lalgies, } \\
\mathbf{N}=\mathbf{3 3}\end{array}$ & \begin{tabular}{|l}
$\begin{array}{c}\text { Abdomi- } \\
\text { nalgies, } \\
\mathrm{N}=15\end{array}$ \\
\end{tabular} & \\
\hline $\begin{array}{l}\text { Overprotect } \\
\text { by parents }\end{array}$ & $5(25,0)$ & $\begin{array}{c}9 * * \\
(64,3)\end{array}$ & $27(81,8)$ & $13(86,7)$ & $54(65,9)$ \\
\hline $\begin{array}{l}\text { Psycholc } \\
\text { lonelines }\end{array}$ & $12(60)$ & $10(71,4)$ & $8(24,2)$ & $12(80,0)$ & $42(51,2)$ \\
\hline $\begin{array}{l}\text { Frequent conflicts with } \\
\text { parents }\end{array}$ & $\begin{array}{c}11^{*} \\
(55,0)\end{array}$ & $5(35,7)$ & $\begin{array}{c}16^{* *} \\
(48,5) \\
\end{array}$ & $6(40,0)$ & $38(46,3)$ \\
\hline Fear & $4(20,0)$ & $11(78,6)$ & $13(39,4)$ & $9(60,0)$ & $37(45,1)$ \\
\hline $\begin{array}{l}\text { Misunderstanding } \\
\text { parents }\end{array}$ & $7(35,0)$ & $7(50,0)$ & $12(36,4)$ & $\begin{array}{c}10^{*} \\
(66,7)\end{array}$ & $36(43,9)$ \\
\hline $\begin{array}{l}\text { Fear not to } \\
\text { expectatio }\end{array}$ & $4(20,0)$ & $6(42,9)$ & $15(45,5)$ & $11(73,3)$ & $36(43,9)$ \\
\hline Meaninglessness & $8 *(40,0)$ & $4(28,6)$ & $6(18,2)$ & $4(26,7)$ & $22(26,8)$ \\
\hline Confli & $8(40,0)$ & $4(28,6)$ & $5(15,2)$ & $2(13,3)$ & $19(23,2)$ \\
\hline $\begin{array}{l}\text { Unsubstantiated claims } \\
\text { of parents }\end{array}$ & $6(30,0)$ & $4(28,6)$ & $6(18,2)$ & $3(20,0)$ & $19(23,2)$ \\
\hline $\begin{array}{l}\text { Conflicts with close } \\
\text { friends }\end{array}$ & $3(15,0)$ & $2 *(14,3)$ & $5(15,2)$ & $2(13,3)$ & $12(14,6)$ \\
\hline $\begin{array}{l}\text { Total (\% of total } \\
\text { patients) }\end{array}$ & $68(82,9)$ & $62(75,6)$ & $\begin{array}{c}113 * * \\
(139,1)\end{array}$ & $72(87,8)$ & $82(100)$ \\
\hline
\end{tabular}

$* p<0,05 ; * * p<0,01$.

In general, each of the teens spoke about the combination of the various problem areas, the stressors in their lives. The largest number of co-traumatic factors were found in the subgroup of young women with Cephalalgies and reached $139.1 \%$ in relation to the total number of patients in this subgroup. In other subgroups stressor level was considerably lower and not greater than $90 \%(\mathrm{p}<0.01)$. The results showed that among girls experiencing psychogenic factors was 
considerably stronger than among young men. The least impact of stressful factors was identified in boys with Abdominalgies ${ }^{8}$.

The most common problem among adolescents surveyed was a sense of overprotection by parents ( $65.9 \%$ of cases). In this case, there was a considerable difference in a similar style of parent-child relationships between boys and girls. Among the girls who suffer Cephalalgies and Abdominalgies, overprotection by parents was observed in almost equal numbers of cases and more than $80 \%$ of patients. And among the young men with Abdominalgies this style of parental behavior was positively detected 2.6 times more likely $(\mathrm{p}<0.01)$.

An important indicator of increased stress vulnerability of adolescents surveyed was the second most common among them experience of psychological loneliness. More than half of patients reported that they felt a similar feeling (51.2\% of adolescents in general). The greatest degree of psychological loneliness was experienced by patients with Abdominalgies - both boys and girls. In this subgroup of girls with Abdominalgies considerably more likely experienced psychological loneliness, compared with those of other subgroups $(p<0.01)$.

Almost half of the surveyed adolescents named frequent conflicts with parents and a sense of fear of the future as traumatic effects - as a whole in 46.3 and $45.1 \%$ of cases, respectively. Constant conflicts with parents were considerably more prevalent in boys with Cephalalgies, and fear of the future - in the young men and women with Abdominalgies $(p<0.05)$. Patients of both sexes with Abdominalgies also considerably more often named a sense of constant misunderstanding of their experiences and the state of the parents as a psychogenic stressor, as well as anxiety and concerns about the inability to meet the expectations of relatives $(\mathrm{p}<0.05)$. These psychogenic factors were not significant for adolescents with Cephalalgies.

Rather important result is the data, that almost every fourth teenager (overall $26.8 \%$ of cases) had a sense of meaningless with respect to his own, which is directly correlated with the severity of depressive symptoms in patients as it is shown in Tables 2 and 3.

A specific feature of these disorders is that in the girls with Cephalalgies (18.2\%) and Abdominalgies (26.7\%) they were less common. At Abdominalgies among both boys and girls a sense of futility was experienced by every fourth patient. The fact, that meaninglessness was considerably more likely experienced by boys with STsfal, indicates

${ }^{8}$ Bräutigam B., Christian, P.M. Glad Psychosomatic Medicine. Moscow, 1999. 376 p. 
a high probability of comorbid transition of somatoform dysfunction syndrome into depressive pathology. This thesis is confirmed by the data that $40.0 \%$ of boys with Cephalalgies had constant conflicts with teachers at school. The majority of patients in this subgroup had constant conflicts with parents (at $55.0 \%$ of cases), experienced a sense of psychological isolation $(60.0 \%)$ and experienced more often than others (30.0\% of cases) unsubstantiated claims, accusations from parents. These data support the conclusion that Cephalalgies in the young men correlates with severe affective (depressive symptoms) and behavioral disorders (oppositional protesting behavior).

Table 3

Distribution of adolescents according to gender, leading pain syndrome (Cephalalgies and Abdominalgies), nature of addictive behavior, absolute amount (\%)

\begin{tabular}{|c|c|c|c|c|c|}
\hline \multirow{3}{*}{$\begin{array}{c}\text { Characteristics } \\
\text { of addictive behavior }\end{array}$} & \multicolumn{5}{|c|}{ Examined patients } \\
\hline & \multicolumn{2}{|c|}{ boys, $N=34$} & \multicolumn{2}{|c|}{ girls, $N=48$} & \multirow[b]{2}{*}{$\begin{array}{l}\text { Total } \\
\text { in } \\
\text { groups }\end{array}$} \\
\hline & $\begin{array}{l}\text { Cepha- } \\
\text { lalgies, } \\
\mathbf{N}=\mathbf{2 0}\end{array}$ & $\begin{array}{c}\text { Abdomi- } \\
\text { nalgies, } \\
\mathbf{N}=14\end{array}$ & $\begin{array}{l}\text { Cepha- } \\
\text { lalgies, } \\
\mathbf{N}=33\end{array}$ & $\begin{array}{c}\text { Abdomi- } \\
\text { nalgies, } \\
\mathrm{N}=15\end{array}$ & \\
\hline $\begin{array}{l}\text { Emotionally dependent } \\
\text { relationship in the family }\end{array}$ & $\begin{array}{c}6 \\
(30,0)\end{array}$ & $\begin{array}{c}9 \\
(64,3)\end{array}$ & $\begin{array}{c}26 \\
(78,8)\end{array}$ & $\begin{array}{c}14 \\
(93,3)\end{array}$ & $\begin{array}{c}55 \\
(67,1)\end{array}$ \\
\hline $\begin{array}{l}\text { Internet addiction } \\
\text { of social networking }\end{array}$ & $\begin{array}{c}8 \\
(40,0)\end{array}$ & $\begin{array}{c}6 \\
(42,9)\end{array}$ & $\begin{array}{c}26 \\
(78,8)\end{array}$ & $\begin{array}{c}7 \\
(46,7)\end{array}$ & $\begin{array}{c}47 \\
(57,3)\end{array}$ \\
\hline $\begin{array}{l}\text { Gaming Internet } \\
\text { addiction }\end{array}$ & $\begin{array}{c}17 \\
(85,0)\end{array}$ & $\begin{array}{c}10 \\
(71,4)\end{array}$ & $\begin{array}{c}7 \\
(21,2)\end{array}$ & $\begin{array}{c}9 \\
(60,0)\end{array}$ & $\begin{array}{c}43 \\
(52,4)\end{array}$ \\
\hline Occasional use of drugs & $\begin{array}{c}12 \\
(60,0)\end{array}$ & $\begin{array}{c}5 \\
(35,7)\end{array}$ & $\begin{array}{c}3 \\
(9,1)\end{array}$ & - & $\begin{array}{c}20 \\
(24,4)\end{array}$ \\
\hline Nicotine Addiction & $\begin{array}{c}13 \\
(65,0)\end{array}$ & $\begin{array}{c}6 \\
(42,9) \\
\end{array}$ & - & - & $\begin{array}{c}19 \\
(23,2)\end{array}$ \\
\hline $\begin{array}{l}\text { Emotionally addictive } \\
\text { relationship with } \\
\text { a partner }\end{array}$ & $\begin{array}{c}4 \\
(20,0)\end{array}$ & - & $\begin{array}{c}6 \\
(18,2)\end{array}$ & $\begin{array}{c}2 \\
(13,3)\end{array}$ & $\begin{array}{c}12 \\
(14,6)\end{array}$ \\
\hline Abuse of alcohol (beer) & $\begin{array}{c}8 \\
(40,0) \\
\end{array}$ & $\begin{array}{c}2 \\
(14,3) \\
\end{array}$ & - & - & $\begin{array}{c}10 \\
(12,2)\end{array}$ \\
\hline Cannabinoid addiction & $\begin{array}{c}6 \\
(30,0) \\
\end{array}$ & - & - & - & $6(7,3)$ \\
\hline $\begin{array}{l}\text { Food addiction } \\
\text { (anorexia) }\end{array}$ & - & - & - & $\begin{array}{c}5 \\
(33,3)\end{array}$ & $\begin{array}{c}5 \\
(6,1)\end{array}$ \\
\hline $\begin{array}{l}\text { Total (\% to number of } \\
\text { patients in group) }\end{array}$ & $\begin{array}{c}70 \\
(350,0)\end{array}$ & $\begin{array}{c}38 \\
(271,4)\end{array}$ & $\begin{array}{c}68 \\
(206,1)\end{array}$ & $\begin{array}{c}37 \\
(246,7)\end{array}$ & $82(100)$ \\
\hline
\end{tabular}


Table 4

Distribution of adolescents, according to the nature of addictive behavior disorders and nosological forms, absolute. amount (\%)

\begin{tabular}{|c|c|c|c|c|c|c|c|c|c|}
\hline \multirow{3}{*}{\begin{tabular}{|c|} 
Characterist \\
ics of \\
addictive \\
behavior \\
\end{tabular}} & \multicolumn{9}{|c|}{ Examined patients } \\
\hline & \multicolumn{8}{|c|}{ Nosological forms of disorders } & \multirow{2}{*}{\begin{tabular}{|c|}
$\begin{array}{c}\text { Total } \\
\text { in } \\
\text { groups }\end{array}$ \\
\end{tabular}} \\
\hline & $\begin{array}{l}\text { F06.6, } \\
\mathrm{N}=6\end{array}$ & $\begin{array}{l}F 32.01 \\
N=10\end{array}$ & $\begin{array}{l}\mathrm{F} 41.0 \\
\mathrm{~N}=10\end{array}$ & $\begin{array}{c}\mathrm{F} 43.21, \\
\mathrm{~N}=7\end{array}$ & \begin{tabular}{|l}
$\mathrm{F} 45.2$, \\
$\mathrm{N}=12$ \\
\end{tabular} & $\begin{array}{l}F 45.30, \\
N=19\end{array}$ & $\begin{array}{c}F 45.31 \\
N=8\end{array}$ & $\begin{array}{l}\mathrm{F} 45.4, \\
\mathrm{~N}=10\end{array}$ & \\
\hline $\begin{array}{l}\text { Emotionally- } \\
\text { addictive } \\
\text { relations in } \\
\text { family }\end{array}$ & $\begin{array}{c}3 \\
(50,0)\end{array}$ & $\begin{array}{c}6 \\
(60,0)\end{array}$ & $\begin{array}{c}6 \\
(60,0)\end{array}$ & $\begin{array}{c}3 \\
(42,9)\end{array}$ & $\begin{array}{c}11 \\
(91,7)\end{array}$ & $\begin{array}{c}16 \\
(84,2)\end{array}$ & $\begin{array}{c}7 \\
(87,5)\end{array}$ & $\begin{array}{c}4 \\
(40,0)\end{array}$ & $\begin{array}{c}55 \\
(67,1)\end{array}$ \\
\hline $\begin{array}{l}\text { social } \\
\text { networking } \\
\text { Internet } \\
\text { addiction }\end{array}$ & $\begin{array}{c}2 \\
(33,3)\end{array}$ & $\begin{array}{c}8 \\
(80,0)\end{array}$ & $\begin{array}{c}7 \\
(70,0)\end{array}$ & $\begin{array}{c}5 \\
(71,4)\end{array}$ & $\begin{array}{c}5 \\
(41,7)\end{array}$ & $\begin{array}{c}13 \\
(68,4)\end{array}$ & $\begin{array}{c}5 \\
(62,5)\end{array}$ & $\begin{array}{c}2 \\
(20,0)\end{array}$ & $\begin{array}{c}47 \\
(57,3)\end{array}$ \\
\hline $\begin{array}{l}\text { Gaming } \\
\text { Internet } \\
\text { addiction }\end{array}$ & $\begin{array}{c}4 \\
(66,7)\end{array}$ & $\begin{array}{c}7 \\
(70,0)\end{array}$ & $\begin{array}{c}3 \\
(30,0)\end{array}$ & $\begin{array}{c}4 \\
(57,1)\end{array}$ & $\begin{array}{c}4 \\
(33,3)\end{array}$ & $\begin{array}{c}10 \\
(52,6)\end{array}$ & $\begin{array}{c}6 \\
(75,0)\end{array}$ & $\begin{array}{c}5 \\
(50,0)\end{array}$ & $\begin{array}{c}43 \\
(52,4)\end{array}$ \\
\hline $\begin{array}{l}\text { Occasional } \\
\text { use of drugs }\end{array}$ & $\begin{array}{c}3 \\
(50,0)\end{array}$ & $\begin{array}{c}4 \\
(40,0)\end{array}$ & $\begin{array}{c}3 \\
(30,0)\end{array}$ & $\begin{array}{c}1 \\
(14,3)\end{array}$ & - & $\begin{array}{c}3 \\
(15,8)\end{array}$ & $\begin{array}{c}1 \\
(12,5)\end{array}$ & $\begin{array}{c}5 \\
(50,0)\end{array}$ & $\begin{array}{c}20 \\
(24,4)\end{array}$ \\
\hline $\begin{array}{l}\text { Nicotine } \\
\text { addiction }\end{array}$ & $\begin{array}{c}3 \\
(50,0) \\
\end{array}$ & $\begin{array}{c}6 \\
(60,0)\end{array}$ & $\begin{array}{c}2 \\
(20,0)\end{array}$ & $\begin{array}{c}3 \\
(42,9)\end{array}$ & - & $\begin{array}{c}1 \\
(5,3)\end{array}$ & - & $\begin{array}{c}4 \\
(40,0) \\
\end{array}$ & $\begin{array}{c}19 \\
(23,2)\end{array}$ \\
\hline $\begin{array}{l}\text { Emotionally } \\
\text { addictive } \\
\text { relationships } \\
\text { with partner }\end{array}$ & - & $\begin{array}{c}2 \\
(20,0)\end{array}$ & - & $\begin{array}{c}7 \\
(100,0 \\
)\end{array}$ & - & - & - & $\begin{array}{c}3 \\
(30,0)\end{array}$ & $\begin{array}{c}12 \\
(14,6)\end{array}$ \\
\hline $\begin{array}{l}\text { Abuse of } \\
\text { alcohol } \\
\text { (beer) }\end{array}$ & $\begin{array}{c}3 \\
(50,0)\end{array}$ & $\mid \begin{array}{c}4 \\
(40,0)\end{array}$ & - & - & - & - & - & $\begin{array}{c}3 \\
(30,0)\end{array}$ & $\begin{array}{c}10 \\
(12,2)\end{array}$ \\
\hline $\begin{array}{l}\text { Cannabinoid } \\
\text { addiction }\end{array}$ & $\begin{array}{c}2 \\
(33,3)\end{array}$ & $\left|\begin{array}{c}2 \\
(20,0)\end{array}\right|$ & $\begin{array}{c}1 \\
(10,0)\end{array}$ & - & - & - & - & $\begin{array}{c}1 \\
(10,0)\end{array}$ & $\begin{array}{c}6 \\
(7,3)\end{array}$ \\
\hline $\begin{array}{l}\text { Food } \\
\text { addiction } \\
\text { (anorexia) }\end{array}$ & - & - & - & - & $\begin{array}{c}3 \\
(25,0)\end{array}$ & - & $\begin{array}{c}2 \\
(25,0)\end{array}$ & - & $5(6,1)$ \\
\hline $\begin{array}{l}\text { Total (\% of } \\
\text { the number } \\
\text { of patients } \\
\text { in the } \\
\text { subgroup) }\end{array}$ & $\begin{array}{c}22 \\
(366,7)\end{array}$ & $\begin{array}{c}37 \\
(370,0)\end{array}$ & $\begin{array}{c}22 \\
(220,0)\end{array}$ & $\begin{array}{c}23 \\
(328,6)\end{array}$ & $\begin{array}{c}22 \\
(183,3)\end{array}$ & $\begin{array}{c}43 \\
(226,3)\end{array}$ & $\begin{array}{c}21 \\
(262,5)\end{array}$ & $\begin{array}{c}27 \\
(270,0)\end{array}$ & $\begin{array}{c}82 \\
(100)\end{array}$ \\
\hline
\end{tabular}


An important factor in understanding the nature of psychogenic basis in the formation Cephalalgies and Abdominalgies in the surveyed adolescents was that the factor of conflicts with close friends was assessed by patients as significant traumatic impact the most rarely generally in $14.6 \%$ of cases and in almost equal proportions in all subgroups. Consequently, problems in family relationships and depressing intrapersonal experiences have a considerable pathogenetic significance in the development of neurotic (somatoform) and behavioral disorders in adolescence. These results were confirmed by rather low significance of conflict situations with teachers at school, for teens (generally in $23.2 \%$ of cases).

The psychosocial basis of Cephalalgies and Abdominalgies as options of somatoform dysfunction syndrome in the form of psychopathological personality characteristics of adolescents and interpersonal problems in their immediate environment has become the pathogenetic basis for the comorbid formation of different options of addictive behavior (the data are presented in Table 3). According to the results of the diagnostic interviews with all the surveyed teenagers it was found that most frequent symptoms of somatoform dysfunction syndrome in the form of pain is comorbid to different types of behavioral addiction. In all subgroups of adolescents several variants of combined behavioral dependence were revealed and, in some cases, the addiction to use of psychoactive substances.

The most common types of behavioral addiction among teenagers in all subgroups were emotionally addicted relationships in family $(67.1 \%)$ and Internet addiction (to social networks $-57.3 \%$ and games $52.4 \%$ ). The prevalence of these types of dependence was considerably higher than the others $(\mathrm{p}<0.05)$. Overall least likely among adolescents surveyed cannabinoid ( $F$ 12.2) and food addiction ( $F$ 50.0) were observed. These data are presented in Table 4.

The fact, that drug addiction was represented only by use of cannabinoids (the use of other types of drug was confirmed by four young men, but as a one-off cases) and was detected in $30.5 \%$ of boys with Cephalalgies, is significant. At the same time anorexia (as a variation of food) addiction) was only observed among 33.3\% of young women with Abdominalgies. Anorexia nervosa (F 50.0), formed as a result of a long and intensive Abdominalgies, was only detected in patients with somatoform dysfunction syndrome of gastrointestinal tract (F 45.31), and hypochondrical disorder (F 45.2). Despite the fact that the 
most clinically serious variations of addictive behavior occurred the most rarely among the examined adolescents in general, these data indicate that it was diagnosed in each of three patients from certain subgroups ${ }^{9}$.

The analysis of the nature of comorbid addictive behavior in respect to each of the variants of pain and to sex of teens revealed the following. Emotionally addictive relationships with mothers were found in the overwhelming majority of young women $(83.3 \%$ overall), that was really more as compared with boys $(44.1 \%, p=0.003)$. But the peculiarity of this variant of comorbidity behavioral addiction was that it was found in $79.3 \%$ of all boys and girls with Abdominalgies. From the point of view of nosologic characteristics emotionally addicted relationships with mothers were presented in patients with hypochondrical disorder (F 45.2) and somatoform dysfunction syndrome ( F 45.30, and (F 45.31) - more than $84 \%$ of cases for each nosology $(\mathrm{p}<0.01)$. The results demonstrating that the emotionally addicted relationships are typical for adolescents with depressive episode (F 32.01), and panic disorder (F 41) - by $60.0 \%$ of the cases in each of nosology, became significant.

The pathophysiological mechanism of the formation of gambling addiction to computer games is based on the stimulation of certain centers of pleasure in the brain. This pathological condition can manifest itself in the form of a feeling of euphoria while visiting the virtual world. Patients with computer addiction cannot plan their time at the computer. To stimulate intellectual activity, they begin to consume large amounts of caffeinated drinks and other psychostimulants.

The regime and quality of food are changing - for gamers, beer and fast food are becoming the main products. A person begins to poorly follow the rules of personal hygiene: he stops combing his hair, brushing his teeth, taking a shower - he becomes indifferent to how he looks and eats.

He usually leads a sedentary lifestyle and does not sleep well. If a computer or smartphone suddenly breaks down, or if a player runs out of money for a game, he is in a depressed mood, can be aggressive with people around him, starts looking for a solution to the problem and, as a rule, does not think about his personal life, work or study.

\footnotetext{
${ }^{9}$ Marincheva L.P., Zlokazova M.V., Solovyev A.G. Socio-psychological and clinical risk factors of somatoform autonomic dysfunction of the cardiovascular system in adolescents. Review of Psychiatry and Medical Psychology of. Spondylitis. 2008. № 1. P. 38-44.
} 
As gambling addiction progresses, the patient cannot give up computer games, although he begins to understand their uselessness. He regularly moves away from reality and plunges into an illusory world, takes on the role of a character and lives his life.

In general, variations the subgroups of Internet addiction had different prevalence depending on the sex of the patients. Internet addiction of social networking greatly prevailed in girls with Cephalalgies $(\mathrm{p}<0.05)$, and game addiction was considerably more common in boys (generally in $79.4 \%$ of cases). Interesting was the fact that Internet addiction of social networking in the least degree was typical for patients with organic disorders of the CNS (F 06.6), chronic pain ( $F$ 45.4) and hypochondrical disorders ( $F$ 45.2). While online gaming addiction was observed at panic (F 41.0) and hypochondrical disorders (F 41.0). Personal qualities such as low self-esteem, inability to control their emotions, lack of desire to accept criticism, aggression, impulsivity and hyperactivity, increased levels of anxiety, depression and stress, a tendency to immerse themselves in a fantasy world, contribute to the development of gambling addiction in adolescents.

Teenagers who HAD SOMATOFORM DYSFUNCTION SYNDROME depressive episode and depressive reaction in the adjustment disorder virtual addiction was inherent in a considerable degree. The fact that Internet addiction was comorbidly formed by manifestations of somatoform dysfunction syndrome and of depressive symptoms, indicated the seriousness of psycho-pathological problems in adolescents, who had somatoform disorders developing together with behavioral disorders, as escape from solving real life problems in relationships with relatives - as a virtual version of self-realization. Internet addiction was more severe in boys than in girls.

This thesis is confirmed by the prevalence among adolescents surveyed of cases of addiction behavior with the use of psychoactive substances.

Deviant behavior, especially associated with drug addiction "debut", occurs in adolescence. The patterns of personality development developed by the leading national scientists (L.S. Vygotsky, P.Ya. Galperin, D.B. Elkonin) are of particular importance in the study of the problems that cause deviant adaptation and behavior disorder in adolescence.

It is known that the adolescent stage of development is characterized by instability and variability, therefore it can act as a factor that contributes to the formation of deviant behavior patterns. By the 
beginning of adolescence, a system of relations between the adolescent and his environment, specific for this period, develops. So, despite the fact that a teenager seeks to be an adult, he spends most of his time in children's society, i.e. society of their peers.

The main reasons provoking the deviant behavior of adolescents are associated not only with the difficulties of adolescence, but also with the disharmony of the personality, the violation of the process of its development, the accentuation of character. A.A. Reana show that a deviant personality is characterized by inadequate selfesteem. In addition, in the profile of her character there are several peaks of disharmony and her social relations are distinguished by a high degree of conflict.

Deviant behavior is considered as a model of violation of the adaptation process, actions (or readiness to commit them) that contradict generally accepted cultural and moral values, socio-psychological and legal norms, including the abuse of alcohol, drugs and other psychoactive substances. In times of instability in society, the risk of deviant social adaptation of young people with the use of narcotic substances increases. Older adolescents (14-18 years old) are at increased risk of drug addiction ${ }^{10}$.

Almost a quarter of all teenagers occasionally used drugs or had nicotine dependence ( 24.4 and $23.2 \%$ of cases). The vast majority of chemical dependence was observed in boys. Various versions of them were considerably more often observed in patients with Cephalalgies $(\mathrm{p}<0.01)$. The most alarming trend was the fact that nicotine (F 17.2), cannabinoid (F 12.2) dependence and abuse of beer (F 10.1) were most typical for young patients with an organic disorder of the central nervous system (F 06.6), depressive episode (F 32.01) and chronic pain disorder ( $F$ 45.4). In these subgroups these types of pathology were diagnosed considerably more often $(p<0.01)$. In a clinical interview with teenagers, it was determined that for patients with a depressive episode ( $F$ 32.01), and chronic pain disorder ( $F$ 45.4) addiction to smoking, alcohol and drugs made it possible to reduce the level of psychalgia and severity of physical pain. While the young men with organic CNS disorder (F 06.6) had chemical addiction formed against the background of impulse-control disorders, oppositional protesting

\footnotetext{
${ }^{10}$ Вислова А.Д. Риски девиантной адаптации у подростков, связанные с потреблением наркотиков, и возможности их профилактики. Национальный психологический журнал. 2018. № 2(30). C. 102-112. DOI: 10.11621/npj.2018.0211.
} 
behavior and involvement in social peer groups, in which use of psychoactive substances was spread. It was an interesting fact that among all patients with a diagnosis of hypochondrical disorder ( F 45.2) there was not a single case of abuse of psychoactive substance.

The formation and presence of symptoms for a long somatoform dysfunction syndrome as pain in the adolescent age potentiates the development of comorbid patients with different types of behavioral and chemical addiction. In all subgroups of adolescents several variants of combined behavioral addiction were revealed. Most often both in young men, and girls emotionally addicted relationship with his mother s (67.1\%) and Internet addiction (54.9\% on average) were fixed. Emotional addicted relationship was most typical for girls with Cephalalgies $(p<0.05)$, whereas Internet addiction did not have significant differences depending on sex of the patient. Almost a quarter of all surveyed teens had various options of substance abuse or chemical dependency syndromes (average of $23.9 \%$ of cases). The vast majority of chemical addiction was observed in young men, and they were observed considerably more frequently in patients with Cephalalgies $(p<0.01)$. Less often among adolescents surveyed cannabinoid (F 12.2) and food addiction (F 50.0) were observed. Cases of anorexia nervosa (F 50.0) were observed only in young women suffering from somatoform dysfunction syndrome of gastrointestinal tract (F 45.31) and hypochondrical disorder (F 45.2).

The most common problem among adolescents surveyed was a sense of overprotection by parents $(65.9 \%$ of the cases in general). In this case, there was a considerable difference in a similar style of parent-child relationships between boys and girls. $51.2 \%$ of adolescents reported that they felt a sense of psychological isolation that is most typical for patients with Abdominalgies. Overall, 46.3 and $45.1 \%$ of the surveyed teens as traumatic effects raported frequent conflicts with parents and fear of the future. Cephalalgies in young men was correlated with severe behavioral and affective disorders.

\section{CONCLUSIONS}

Thus, the study found that among the patients examined adolescents who have been diagnosed Cephalalgies considerably prevailed over those who had Abdominalgies. Leading etiological basis of pain in adolescence is different variants of somatoform disorders. Significant contribution to the genesis of Cephalalgies and Abdominalgies is also made by affective neurotic disorders. 
Chronic stress situations have occurred in each of the surveyed patients. Each of the teens pointed to a combination of problems of stress in their lives. In general, among young women the traumatic impact on the formation of SOMATOFORM DYSFUNCTION SYNDROME was considerably stronger than among young men. The largest number of cotraumatic factors was found in the subgroup of young women with Cephalalgies. The least impact of stressful factors was observed in boys with Abdominalgies.

It is important to note that all the examined patients did not consult with psychiatrist in proper time, as the chief complaint among adolescents were headache and abdominal pain, masking mental disorders. Consequently, the SOMATOFORM DYSFUNCTION SYNDROME, accompanied by severe pain in adolescence - is pathogenetically complex and combined mental disorder, which needs adequate psychopharmacological and psychotherapeutic intervention.

\section{SUMMARY}

All adolescents had combine negative life events in their life. Girls felt psychotraumatic experience more strongly than young man. The greatest combine negative life experience has been revealed in a subgroup of girls with HAS. The least influence of psychotraumatic factors was observed at young men with APS.

For all patients it has been diagnosed comorbid combination of various behavioural addictions and abuse syndromes with HAS and APS. More often emotional-dependent relations with mother $(67,1 \%)$ and internet abuse $(54,9 \%)$ were fixed. On the average, at $23,9 \%$ of teenagers various variants of nicotine, alcohol and drug abuse were observed.

\section{REFERENCES}

1. Smulevich A.B. Psychosomatic disorders. Manual of Psychiatry (Eds. Tiganova A.S.). Moscow : Medicine, 2000. P. 466-490.

2. Oleh V. Chernyshov, Maksim Y. Zak, Nataliia N. Shawlis, Svetlana V. Zhuk. Pain as leading syndrome of the somatoform disorders at the pediatricks Wiadomości Lekarskie. 2020. № 73(6). P. 1114-1118 DOI: 10.36740/WLek202006106.

3. Timerbulatov I.F., V.L. Yoldashev Neurotic disorders in children and adolescents: the mechanisms of formation in the context of the impact of factors microsocial. Review of Psychiatry and Medical Psychology them. Spondylitis. 2008. № 2. P. 28-33. 
4. Antropov Y.F. Psychosomatic disorders in children and adolescents. Moscow, 1997. 198 p.

5. Isaev D.N. Psychosomatic disorders in children. St. Petersburg : Peter, 2000. 512 p.

6. The classification of mental and behavioral disorders. Clinical descriptions and guidelines for the diagnosis. Kiev : Fact, 1999. 272 p.

7. Mendelevich V.D. Soloviev S.L. Nevrozologiya and psychosomatic medicine. Moscow : MEDpress-Inform, 2002. $608 \mathrm{p}$.

8. Bräutigam B., Christian, P., M. Glad Psychosomatic Medicine. Moscow, 1999. 376 p.

9. Marincheva L.P., Zlokazova M.V., Solovyev A.G. Socio-psychological and clinical risk factors of somatoform autonomic dysfunction of the cardiovascular system in adolescents. Review of Psychiatry and Medical Psychology of Spondylitis. 2008. № 1. P. 38-44.

10. Вислова А.Д. Риски девиантной адаптации у подростков, связанные с потреблением наркотиков, и возможности их профилактики. Нащиональный психологический журнал. 2018. № 2(30). C. 102-112 DOI: 10.11621/npj.2018.0211.

\section{Information about the authors: \\ Chernyshov O. V.,}

Candidate of Medical Sciences, Associate Professor at the Department Therapeutic and Surgical Disciplines

Petro Mohyla Black Sea National University 10, 68 Desantnykiv str., Mykolaiv, 54003, Ukraine

Zak M. Yu., Doctor of Medical Sciences, Professor at the Department Therapeutic and Surgical Disciplines

Petro Mohyla Black Sea National University 10, 68 Desantnykiv str., Mykolaiv, 54003, Ukraine 